\title{
FORESTRY UPDATE
}

\section{Supreme Court Rules in Favour of Alpac}

The Supreme Court of Canada has rejected a request by two Alberta environmental groups to block the $\$ 1.3$ billion Alberta Pacific Forest Industry's pulp and paper project in the north of that province. The Friends of the Athabasca and the Prosperity Environmental Association had their leave to appeal rejected and they will have to pay court costs.

\section{Stora Forest Industries to Expand NS Pulpmill}

Stora Forest Industries in Port Hawkesbury, NS recently unveiled plans for the expansion of their pulpmill and a major recycling project. Stora lost money in 1991-92 and will lose again in 1992-93; however the next few years are looking brighter for the newsprint industry. 1993-95 are predicted to provide a steady improvement in the market leading to 1995 when profits are expected to be respectable in terms of return on investment. The projects announced include secondary treatment for their mill effluent and a recycling project with costs over $\$ 160$ million.

\section{BC Sawmill to Close}

One of five sawmills in the Williams Lake, BC area that has been cutting beetle-killed timber, has announced plans to close, eliminating 110 jobs. The mill, owned by Weldwood, is to be phased out in 1994 when the allowable cut which had been increased as a result of the beetle kill will be reduced. The annual allowable cut for the Williams Lake timber supply area has been reduced from 3.9 million cubic metres a year in 1992 to 2.8 million cubic metres by 1994

\section{NB Woodlot Owners Protest Forest Policy}

Loggers and woodlot owners in NB were pushing the provincial government to have workers cut wood on crown lands before companies are allowed to bring in mechanical harvesters. More than 100 cutters staged a protest where some of the harvesting equipment was being used. The cutters are also upset that the Miramichi campus of the New Brunswick Community College offers a course in the operation of mechanical harvesters. The twelve week course was set up as a result of a request from the NB Forest Products Association.

\section{Weyerhaeuser Proposes to Spray Against Budworm}

Weyerhaeuser in Saskatchewan has proposed to spray 35,000 hectares with $\mathrm{Bt}$ for spruce budworm. About 7700 hectares were sprayed last year and the spraying proved to be $86 \%$ effective. The Saskatchewan Forest Conservation network has asked the province to place at least a one-year moratorium on the use of the biological pesticide until more is known about the effects of it and has suggested that the province conduct an environmental impact study and a wildlife inventory on the area designated for spraying. Research indicates that the pesticide has been used safely across Canada and around the world for about thirty years.

\section{Concerns Expressed About Alberta Reorganization}

Former Alberta Forestry Minister Leroy Fjordbotten suggested that the amalgamation of three departments into the new Department of Environmental Protection, Forests. Parks and Wildlife will result in huge costs and has resulted in tremendous decrease in morale. Brian Evans the Minister of the new department agrees morale is low but disputes claims that the merger will prove more costly than the status quo. He said that the plan is to use everything they have in stock including business cards and letterhead before it is replaced. The morale problem can be chalked up to uncertain times, he suggested and that it will be improved with better communications. He said that it makes sense to bring the often conflicting departments together and saw it as a good way of forcing people to communicate and resolve issues.

\section{PEI Organizations want New Agreement}

Various organizations concerned with forestry in Prince Edward Island are pushing the governments hard to sign a new five-year forestry agreement. Funding for the agreement will come from the Atlantic Canada Opportunities Agency, who have agreed so far to a one-year deal. Prior to the PEI election. Catherine Colbeck said that if she was elected she would be contacting John Crosbie to stress the importance of the industry to the Island. Several federal MPs have also promised to do what they could in Ottawa to get the decision altered.

\section{Unions Concerned About NAFTA}

Unions representing 70,000 forestry and paper workers have suggested that the North American Free Trade Agreement will threaten the management of Canada's forests. They suggest that the agreement could strengthen US arguments against the practice of provincial crown land being leased to forest companies. This would in turn lead to weaker reforestation and other management policies.

\section{"Brazil of the North" Published}

Early in February the publication Brazil of the North was distributed in Europe. The publication was published by a New Denver, $\mathrm{BC}$ based environmental society and distributed in Europe by Greenpeace International. The front cover of the paper depicts a massive clearcut on Vancouver Island and an explanation that one acre of forest is clearcut every 12 seconds. The arrival of the paper was timed with the visit of BC Premier Mike Harcourt and was followed by a visit from Patrick Moore, a director of the Forest Alliance of $\mathrm{BC}$. 